\title{
Are Polish Public Companies "Cooking The Books"? The Evidence From Annual Earnings Thresholds
}

Jacek Welc, Wroclaw University of Economics, Poland

\begin{abstract}
Earnings management erodes the usefulness of financial statements, because the typical result of "cooking the books" is the occurrence of "earnings bubble" that bursts sooner or later, causing stock price to dive. This paper explores the presence of earnings management in the case of companies listed on the Warsaw Stock Exchange in 2000-2009 period. We used the methodology based on two earnings thresholds: the negative / positive annual earnings threshold and the threshold between the decrease / increase of annual earnings. The research found that there is unusually low number of observations with the net margin between $-1,5 \%$ and $0 \%$ and unusually high number of observations with the net margin between $0 \%$ and $2 \%$, which suggests that companies with unmanaged earnings just below zero boost those earnings to the levels just above zero. The research also confirmed (although less strongly than in the case of negative / positive net margin threshold) the earnings management around zero earnings growth, which suggests that companies with unmanaged earnings that would show the small decline $y / y$ boost those earnings in order to report the positive growth at the level just above zero.
\end{abstract}

Keywords: earnings management; earnings manipulations; quality of earnings; earnings thresholds

\section{INTRODUCTION}

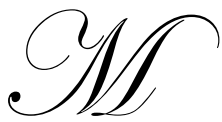

anagers are often tempted to manipulate reported earnings. Usually earnings manipulations are associated with earnings overstatements. There are many ways in which managers can "cook the books". But it's important to note that many of the earnings management techniques are quite "subtle" and can be used within the boundaries of accounting rules (this is so-called aggressive accounting, which is different from fraudulent accounting). This is so because most accounting rules provide significant amount of leeway and require a lot of subjectivity in the process of financial statement preparation. This is problematic from the investors' point of view because aggressive earnings management, although allowed by accounting rules, significantly distorts the quality of reported earnings.

Earnings management erodes the usefulness of financial statements in making investment decisions, because the typical result of managing earnings is the occurrence of "earnings bubble". This bubble bursts sooner or later (usually with negative earnings surprise), causing stock price to dive. That usually happens after the room for further earnings overstatement has disappeared. Barton and Simko (2002) found that managers' ability to optimistically bias earnings decreases with the extent to which the balance sheet already overstates net assets relative to a neutral application of accounting rules. This implies negative correlation between earnings overstatement and future stock returns. The empirical research confirmed that there is a reliable, negative association between earnings overstatement and future stock returns: increases in earnings, when "books are cooked", are associated with sub-par returns (Chan, Chan, Jegadeesh and Lakonishok, 2001).

This paper explores the presence of earnings management in the case of companies listed on the Warsaw Stock Exchange in 2000-2009 period. We used the research methodology based on two earnings thresholds: the negative / positive annual earnings threshold and the threshold between the decrease / increase of annual earnings. 
The remainder of the paper is organized as follows. In the next section we provide the literature review and then we describe the data and methodology used in the study. After that the section that presents the empirical results follows. The paper closes with concluding comments.

\section{LITERATURE REVIEW}

Empirical research generally corroborates that managers try to manage earnings in order to achieve some personal or corporate goals (e.g. receive pay bonuses based on earnings or decrease cost of debt). Scholer (2006) found that Danish firm managers engage in earnings management to avoid small losses. Other research based on Belgian companies found that firms manage accruals to smooth income (Vander Bauwhede, Willekens and Gaeremynck, 2003). Salamon and Stober (1994) found that fourth-quarter earnings contain more earnings management than earnings from other quarters, which suggests that managers attempt to achieve annual earnings targets via discretionary accounting choices. One research found that companies in IAS / IFRS environment use the available accounting flexibility to meet or beat consensus forecasts (Babalyan, 2004).

Among the strongest motivations for earnings management are high market expectations regarding earnings growth of so-called "growth stocks" (i.e. companies historically experiencing rapid growth of earnings and usually having high valuation multiples). Richardson, Tuna and Wu (2002) found that firms forced to restate earnings have high market expectations for future earnings growth and have higher levels of outstanding debt and that restating firms are attempting to maintain a string of consecutive positive earnings growth and consecutive positive quarterly earnings surprises. Myers and Skinner (2006) found that managers of firms with long strings of increases in quarterly EPS have strong incentives to maintain these strings and that these firms enjoy unusually strong stock performance in the period they report increases in EPS and suffer large stock price declines around the time their earnings start to decline. The other research corroborates that manipulating firms usually show strong earnings performance prior to the earnings manipulations, which suggests that manipulations appear to be motivated by managements' desire to disguise a moderating financial performance (Dechow, Ge, Larson and Sloan, 2010). The same research confirms that manipulating firms' stock returns outperform the broader market in the years leading up to the manipulation and underperform in the years following the manipulation.

The popular method of examining the presence of earnings management is the analysis of earnings distributions around so-called earnings thresholds. The analytical methodology based on cross-sectional distribution of reported earnings in examining the extent to which companies manage earnings was first introduced by Hayn (1995). This approach was then refined by Burgstahler and Dichev (1997). The three thresholds that are usually examined are: the threshold between reporting losses / profits, the threshold between reporting decrease / increase of earnings and the threshold between meeting / missing the market earnings expectations.

Degeorge, Patel and Zeckhauser (1998) state that empirical explorations find clear support for earnings management to exceed each of the three thresholds stated above. Charoenwong and Jiraporn (2008) found the evidence of earnings management to avoid reporting losses and negative earnings growth in Singapore and Thailand. The same authors state that corporate governance structure impacts the extent of earnings management to exceed thresholds in Singapore. Lai (2009) found that the likelihood of managing earnings to meet thresholds is negatively related to the adoption of independent directors in the board of directors and to the percentage shareholdings of the largest shareholder and positively related to the percentage share of state ownership. However, Brown and Caylor (2005) state that since the mid-1990s, but not before then, investors rewarded (penalized) firms for reporting quarterly earnings meeting (missing) analysts' estimates more then they did for meeting (missing) the other two thresholds. Daniel, Denis and Naveen (2008) found that managers treat expected dividend levels as another important earnings threshold and because of this firms are more likely to manage earnings upward when their earnings would otherwise fall short of expected dividend levels. The other research states that there is unusual pattern in the second digit of reported earnings-per-share (EPS) and that the second digit of EPS is more likely to be zero and five and less likely to be nine for profit firms (Jorgensen, Lee, Rock, 2010).

It's important to note that Herrmann, Hope, Payne and Thomas (2010) found no significant evidence of incremental threshold effects in market reaction beyond meeting analyst forecasts. These researchers conclude that this means that either managers have other incentives to manage earnings (than to boost stock price) or that managers perceive market rewards and penalties when none exist. 


\section{RESEARCH METHODOLOGY}

In this research the data concerning annual net earnings of companies listed on the Warsaw Stock Exchange were used. The historical financial results were obtained from Notoria Serwis database. In the sample we included the companies for which all the necessary data were available. Due to significant accounting differences we omitted all the financial companies as well as The National Investment Funds.

In the empirical research we explored two earnings thresholds: the negative / positive annual earnings threshold and the threshold between the decrease / increase of annual earnings. We didn't analyze the threshold between meeting / missing consensus earnings forecasts, because in the case of the Polish stock market the analysts forecasts are available only for quite small number of companies (hence the sample would be too small). We also omitted other potential thresholds (e.g. dividends threshold) because of the lack of any reliable database embracing the necessary data.

The threshold studies usually use non-parametric methods to measure irregularities around the earnings thresholds and the discontinuity is measured by the difference between an observed population and a theoretical population locally estimated by interpolation of adjacent intervals (Vidal, 2008). Many studies are based on the assumption of some specific theoretical distribution of earnings (e.g. normal distribution). However, this approach, although probably theoretically optimal, is not always practically viable, because one need to assume the type of earnings distribution and the theoretical and empirical distribution of Polish companies earnings is not known. Moreover, according to Holland (2004), the assumption of distribution symmetry used by many researchers to test for the prevalence of earnings management can only be justified where there is known symmetrical distribution. Because this distribution is not known we use the different approach: we smoothed the empirical distribution of earnings with the use of Hodrick-Prescott filter (described with details e.g. in the work of Guay and St-Amant, 1996) and then we computed the differences between the observed population and the smoothed population.

In order to standardize the observations in the case of the negative / positive earnings threshold we based the research on the net margin ratio computed as follows:

$N M_{t}=\frac{N E_{t}}{S_{t}}$,

where:

$N M_{t}$ - net margin of a given company in year $t$,

$N E_{t}$ - reported net earnings of a given company in year $t$,

$S_{t}$ - reported net sales of a given company in year $t$.

In the case of this threshold we used the data covering ten-year period between 2000 and 2009. However, we focused only on the observations in which case the net margin computed according to the formula (1) was in the range between $-10 \%$ and $10 \%$ (in order to omit the potential outliers that are not informative for the research). Given this timeframe and the allowed range of profitability we obtained total of 2016 firm-year observations. Then we sorted all the observations in order of increasing profitability and we subjectively divided the whole sample into forty sub-samples so that the first sub-sample embraced the observations with the net margin between $-10 \%$ and $9,5 \%$, the second sub-sample embraced the observations with the net margin between $-9,5 \%$ and $-9 \%$ and so on. Then we computed the number of observations within each sub-sample. This gave us the empirical distribution of the net margin in 2000-2009 years. Then we smoothed the observed empirical distribution with the use of the Hodrick-Prescott filter. Finally we computed the differences between the observed and smoothed number of observations within all the sub-samples and we carried out the visual evaluation of the irregularities around $0 \%$ profitability (i.e. around the negative / positive earnings threshold). 
In the case of the threshold between decrease / increase of earnings we based the research on the growth of annual earnings measured as follows:

$$
N E G_{t}=\frac{N E_{t}}{N E_{t-1}}-1,
$$

where:

$N E G_{t}$ - growth of net earnings of a given company in year $t$,

$N E_{t}$ - reported net earnings of a given company in year $t$.

In this case we used the data covering nine-year period between 2001 and 2009 (because we lost one year of observations when computing earnings growth). However, we focused only on the observations in which case the change in net earnings computed according to the formula (2) was in the range between -90\% and $90 \%$ (in order to omit the potential outliers that are not informative for the research). We also omitted any observations with negative earnings in any of the two years entering the formula (2) for the earnings growth (in order to delete the observations with potentially nonsensical computed earnings growth). Given this timeframe and the described sample limitations we obtained total of 1183 firm-year observations. Then we sorted all the observations in order of increasing earnings growth and we subjectively divided the whole sample into ninety sub-samples so that the first sub-sample embraced the observations with the decline of net earnings between $-90 \%$ and $-88 \%$, the second sub-sample embraced the observations with the decline of net earnings between $-88 \%$ and $-86 \%$ and so on. Then we computed the number of observations within each sub-sample. This gave us the empirical distribution of the net earnings growth in 20012009 years. Then we smoothed the observed empirical distribution with the use of the Hodrick-Prescott filter. Finally we computed the differences between the observed and smoothed number of observations within all the subsamples and we carried out the visual evaluation of the irregularities around $0 \%$ net earnings growth (i.e. around the decrease / increase of earnings threshold).

The summary statistics computed for both analyzed variables are presented in Table 1 .

Table 1: Summary statistics computed for net margin* and net earnings growth** of the companies listed on the Warsaw Stock Exchange.

\begin{tabular}{|l|c|c|c|c|c|c|}
\hline \multicolumn{1}{|c|}{ Variable } & $\begin{array}{c}\text { Number of } \\
\text { observations }\end{array}$ & $\begin{array}{c}\text { Arithmetic } \\
\text { average }\end{array}$ & Median & $\begin{array}{c}\text { Standard } \\
\text { deviation }\end{array}$ & $\begin{array}{c}\text { Coefficient of } \\
\text { variation**** }\end{array}$ & $\begin{array}{c}\text { Coefficient } \\
\text { of asymmetry**** }\end{array}$ \\
\hline $\begin{array}{l}\text { Net margin* } \\
\begin{array}{l}\text { Net earnings } \\
\text { growth** }\end{array}\end{array}$ & 2,016 & $2.6 \%$ & $2.6 \%$ & $4.0 \%$ & $156.2 \%$ & 0.12 \\
-0.07 & $3.9 \%$ & $7.1 \%$ & $45.5 \%$ & $1,171.5 \%$ & -0.07 \\
\hline
\end{tabular}

$*$ as defined by equation (1)

** as defined by equation (2)

*** standard deviation / arithmetic average

**** metric normalized in the range [-1;1], having zero value in the case of perfect symmetry, negative value in the case of distribution skewed to the left and positive value in the case of distribution skewed to the right; the higher the absolute value the higher the asymmetry of the distribution

Source: Notoria Serwis; author's calculations.

\section{RESEARCH RESULTS}

Chart 1 presents the empirical and smoothed distribution of net margin of companies listed on the Warsaw Stock Exchange in 2000-2009 years. As can be seen, there was the significant irregularity in the range between $1,5 \%$ and $2 \%$. There is unusually low (as compared to the line of smoothed distribution) number of observations with the net margin between $-1,5 \%$ and $0 \%$ (three bars to the left from $0 \%$ bar) and there is unusually high number of observations with the net margin between $0 \%$ and $2 \%$ (five bars to the right from $0 \%$ bar). This is even more discernible on Chart 2 which presents the differences between the observed population and the smoothed population. From this chart we can see that the bars are hovering around 0 in the case of net profitability below $-2 \%$ and above 
$2 \%$. However, there is sharp "shortage" of observations (the bars significantly below 0 ) with the net margin between $-2 \%$ and $0 \%$ and there is sharp "excess" of observations (the bars significantly above 0 ) with the net margin between $0 \%$ and $2 \%$.

This seems to constitute the strong confirmation of the earnings management around zero-profitability threshold. It suggests that many companies with unmanaged earnings just below zero intentionally and artificially boost those earnings to the levels just above zero (i.e. they report fictitious small profits instead of actual small losses).

Chart 1: Actual and smoothed* distribution of annual net margin*** of the companies listed on the Warsaw Stock Exchange in 2000-2009 years.

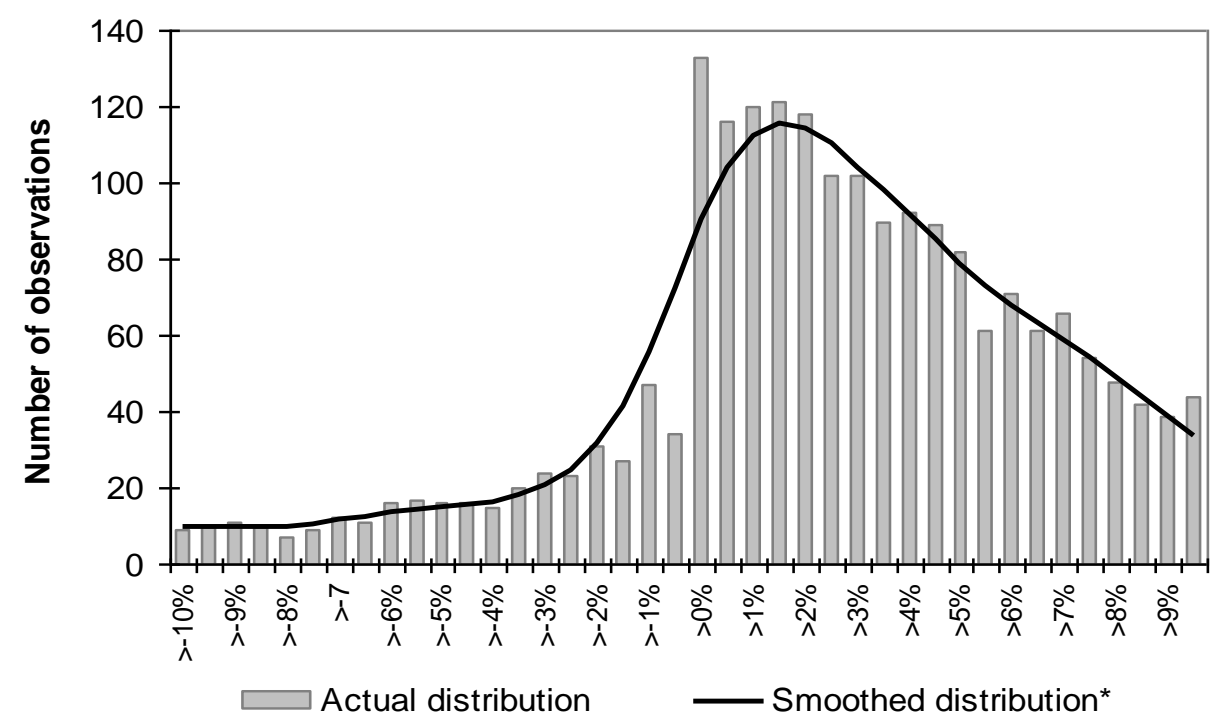

* smoothed with the use of Hodrick-Prescott filter

** reported net earnings of a given company in year $t /$ reported net sales of a given company in year $t$ Source: Notoria Serwis; author's calculations.

Chart 2: The differences between actual and smoothed distribution of annual net margin of the companies listed on the Warsaw Stock Exchange in 2000-2009 years.

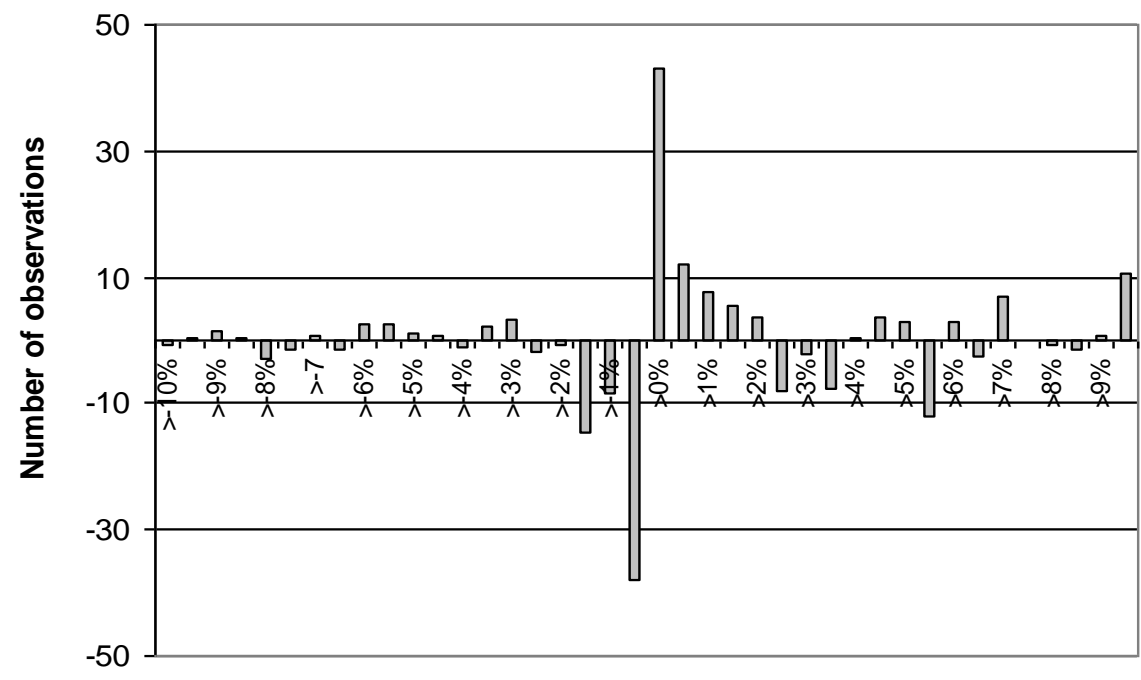

Source: Notoria Serwis; author's calculations. 
Chart 3 presents the empirical and smoothed distribution of the growth of net earnings of companies listed on the Warsaw Stock Exchange in 2001-2009 years. As can be seen, there is significant upside deviation from the smoothed distribution in the range between $0 \%$ and $2 \%$ growth of net earnings (although there's not the break below $0 \%$ as outstanding as in the case of net margin). Chart 4 presents the differences between the observed population and the smoothed population. From this chart we can see that the bars are hovering around 0 in the ranges of net earnings growth between $-90 \%$ and $0 \%$ and between $2 \%$ and $90 \%$. However, there is significant "excess" of observations (the bar significantly above 0 ) with the net earnings growth between $0 \%$ and $2 \%$.

Chart 3: Actual and smoothed* distribution of the growth of annual net earnings of the companies listed on the Warsaw Stock Exchange in 2001-2009 years.

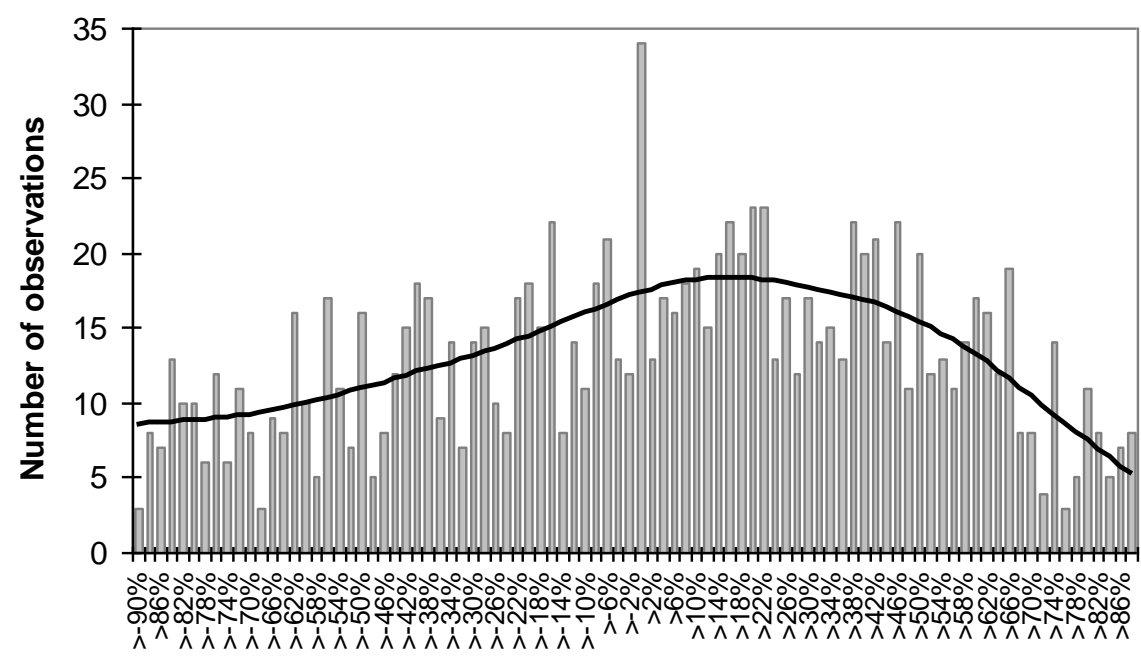

$\square$ Actual distribution $\quad-$ Smoothed distribution*

* smoothed with the use of Hodrick-Prescott filter

Source: Notoria Serwis; author's calculations.

Chart 4: The differences between actual and smoothed distribution of the growth of annual net earnings of the companies listed on the Warsaw Stock Exchange in 2001-2009 years.

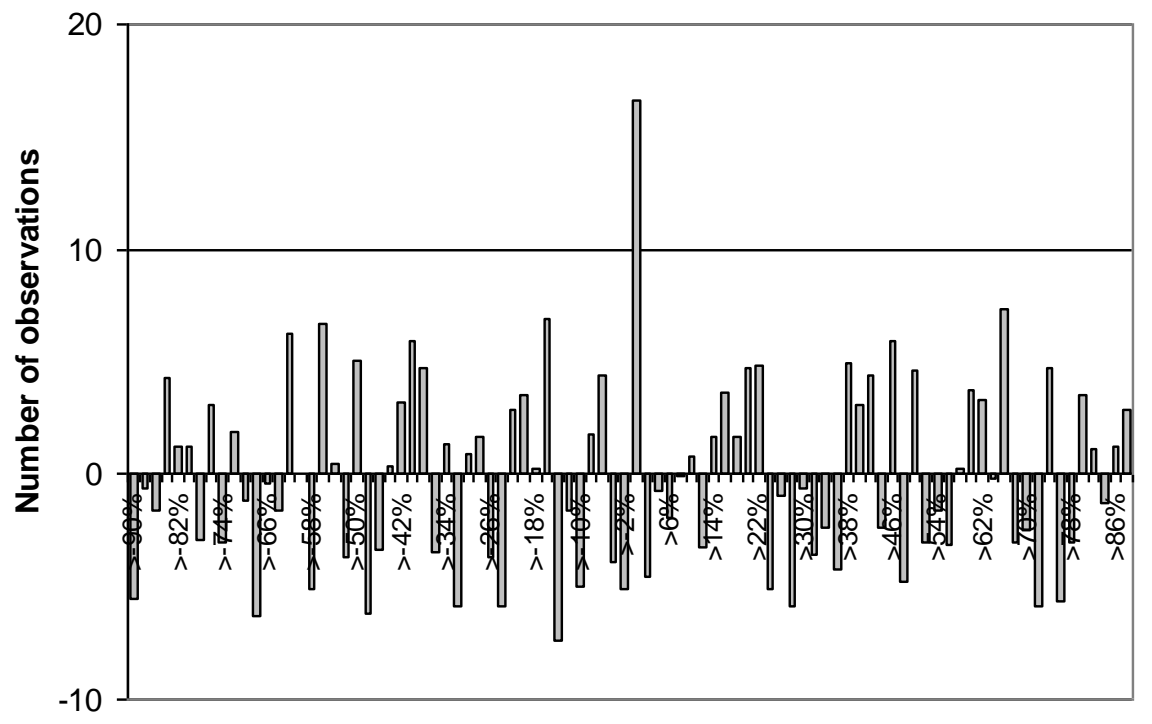

Source: Notoria Serwis; author's calculations. 
This seems to constitute the confirmation (although less strong and evident than in the case of negative / positive net margin threshold) of the earning management around threshold of zero earnings growth. It suggests that many companies with unmanaged earnings that would show the small earnings decline $y / y$ intentionally and artificially boost those earnings in order to report the positive growth at the level just above zero (i.e. they report fictitious small earnings growth instead of actual small earnings decline).

\section{CONCLUSIONS}

Managers are often tempted to manipulate reported earnings. Usually earnings manipulations are associated with earnings overstatements. The popular method of examining whether the companies "cook the books" is the analysis of earnings distributions around so-called earnings thresholds. The three thresholds that are usually examined are: the threshold between reporting losses / profits, the threshold between reporting decrease / increase of earnings and the threshold between meeting / missing the market earnings expectations. In this paper we explored two earnings thresholds of the companies listed on the Warsaw Stock Exchange: the negative / positive annual earnings and the threshold between the decrease / increase of annual earnings. We didn't analyze the threshold between meeting / missing consensus earnings forecasts, because in the case of the Polish stock market the analysts forecasts are available only for quite small number of companies (hence the sample would be too small).

The comparison of the empirical and smoothed distribution of net margin of companies listed on the Warsaw Stock Exchange in 2000-2009 years showed that there was the significant irregularity in the range between $-1,5 \%$ and $2 \%$. There is unusually low number of observations with the net margin between $-1,5 \%$ and $0 \%$ and unusually high number of observations with the net margin between $0 \%$ and $2 \%$. This seems to constitute the strong confirmation of the earnings management around zero-profitability threshold. It suggests that many companies with unmanaged earnings just below zero intentionally and artificially boost those earnings to the levels just above zero (i.e. they report fictitious small profits instead of actual small losses).

The comparison of the empirical and smoothed distribution of the growth of net earnings of companies listed on the Warsaw Stock Exchange in 2001-2009 years showed that there is significant upside deviation in the distribution in the range between $0 \%$ and $2 \%$ growth of net earnings (although there's not the break just below $0 \%$ as outstanding as in the case of net margin). This seems to constitute the confirmation (although less strong and evident than in the case of negative / positive net margin threshold) of the earnings management around zero earnings growth threshold. It suggests that many companies with unmanaged earnings that would show the small earnings decline $y / y$ intentionally and artificially boost those earnings in order to report the positive growth at the level just above zero (i.e. they report fictitious small earnings growth instead of actual small earnings decline).

\section{AUTHOR INFORMATION}

Dr Jacek Welc is an Assistant Professor of Economics at Wroclaw University of Economics. He is also the President of the Board and Chief Economist at WNP Ekspert Consulting (company specialized in corporate valuations).

\section{REFERENCES}

1. Babalyan L. (2004): Earnings Management by Firms Applying International Financial Reporting Standards: Implications for Valuation, Univeristy of Fribourg Doctoral Dissertations.

2. Barton J., Simko P. (2002): The Balance Sheet as an Earnings Management Constraint, Available at SSRN: http://ssrn.com/abstract=320641 or doi:10.2139/ssrn.320641

3. Brown L. D., Caylor M. L. (2005): A Temporal Analysis of Quarterly Earnings Thresholds: Propensities and Valuation Consequences, The Accounting Review, Vol. 80 No. 2, p. 423-440

4. Burgstahler D., Dichev I. (1997): Earnings Management to Avoid Earnings Decreases and Losses, Journal of Accounting and Economics 24(1), p. 99-126

5. Chan K., Chan L. K. C., Jegadeesh N., Lakonishok J. (2001): Earnings Quality and Stock Returns: the Evidence from Accruals, NBER Working Paper Series w8308, pp., Available at SSRN: http://ssrn.com/abstract=272119 
6. Charoenwong Ch., Jiraporn P. (2008): Earnings Management to Exceed Thresholds: Evidence from Singapore and Thailand, Available at SSRN: http://ssrn.com/abstract=1104523

7. Daniel N. D., Denis D. J., Naveen L. (2008): Do Firms Manage Earnings to Meet Dividend Thresholds?, Journal of Accounting and Economics, Vol. 45 Issue 1, p. $2-26$

8. Dechow P. M., Ge W., Larson Ch. R., Sloan R. G. (2010): Predicting Material Accounting Misstatements, Available at SSRN: http://ssrn.com/abstract=997483

9. Degeorge F., Patel J., Zeckhauser R. J. (1998): Earnings Management to Exceed Thresholds, CEPR Discussion Paper 1790

10. Guay A., St-Amant P. (1996): Do Mechanical Filters Provide a Good Approximation of Business Cycles?, Bank of Canada Technical Reports.

11. Hayn C. (1995): The Information Content of Losses, Journal of Accounting and Economics 20(2), p. 123153

12. Herrmann D., Hope O-K., Payne J. L., Thomas W. B. (2010): The Market's Reaction to Unexpected Earnings Thresholds, Available at SSRN: $\underline{\text { http://ssrn.com/abstract=1595149 }}$

13. Holland D. (2004): Earnings Management: A Methodological Review of the Distribution of Reported Earnings Approach, Available at SSRN: $\underline{\text { http://ssrn.com/abstract=525242 }}$

14. Jorgensen B. N., Lee Y. G., Rock S. (2010): Numbers Games? A Natural Experiment Investigating Three (Ir)regularities in Reported Earnings Per Share, American Accounting Association, 2010 Financial Accounting and Reporting Section Mid-Year Meeting, San Diego, California.

15. Lai L. (2009): Management Earnings to Meet Critical Thresholds and the Role of Corporate Governance: A Case Study of China, CAAA Annual Conference 2009 Paper. Available at SSRN: http://ssrn.com/abstract=1326191

16. Myers L. A., Skinner D. J. (2006): Earnings Momentum and Earnings Management, Available at SSRN: http://ssrn.com/abstract=741244 or doi:10.2139/ssrn.741244

17. Richardson S., Tuna I., Wu M. (2002): Predicting Earnings Management: the Case of Earnings Restatements, Available at SSRN: http://ssrn.com/abstract=338681

18. Salamon G. L., Stober T. L. (1994): Cross-quarter differences in stock price responses to earnings announcements: Fourth-quarter and seasonality influences, Contemporary Accounting Research, Vol. 11 Issue 1, p. 297-330

19. Scholer F. (2006): Is There Something Rotten in Denmark? A True Story About Earnings Management to Avoid Small Losses, Financial Reporting Research Group Working Papers

20. Vander Bauwhede H., Willekens M., Gaeremynck A. (2003): Audit Quality, Public Ownership and Firm's Discretionary Accruals Management, International Journal of Accounting, 38 (1), p. 1-22

21. Vidal O. (2008): Gestion Du Résultat et Seuils: Les Montants Manipulés Sont-Ils Marginaux?, Available at: http://ideas.repec.org/p/hal/journl/halshs-00525998_v1.html 